$14^{\text {th }}$ Conf. Agric. Develop. Res., Fac. of Agric.,

Ain Shams Univ., March, 2019., Cairo, Egypt

Special Issue, 27(1), 585 - 593, 2019

Website: http://strategy-plan.asu.edu.eg/AUJASCI/

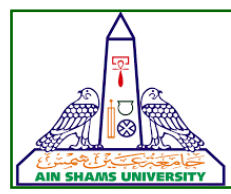

585

\title{
ASSESSMENT OF GENOTOXIC EFFECTS OF SOME FOOD ADDITIVES ON SOME HUMAN CANCER CELLS
}

Shimaa E. Rashad ${ }^{1}$, Abdel-Tawab, F.M. ${ }^{2}$, Eman M. Fahmy ${ }^{2}$, Attallah, A.G. ${ }^{1}$, Ekram S. Ahmed ${ }^{1}$ and Haggran A.A. ${ }^{1}$

1. National Research Center, Dokki, Giza, Egypt

2. Genetic Dept., Fac. of Agric., Ain Shams Univ., P.O. Box 68, Hadyek Shoubra11241, Cairo, Egypt

*Corresponding author: shimaar30@yahoo.com

Received 18 December, 2018,

Accepted 30 December, 2018

\section{ABSTRACT}

Some food additives commonly used by humans have been recently proved to be mutagenic. It is of significant importance to evaluate their genotoxic effects, since they are frequently consumed by humans in their daily meals. In this study, we investigated the effects of monosodium glutamate (MSG), sodium benzoate (SB) and saffron on human cell lines; lung cancer (A549), breast cancer (MCF7), colon cancer (Caco-3) and normal lung (Wi38) cell line as control. Cytotoxicity of food additives was screened on multiple cell lines and examined by $N R$ assay (Neutral Red assay). The present study focused on the cytotoxic activity of the food additives and its possible underlying mechanisms. The results showed that food additives; MSG, SB and saffron induced profound cytotoxicity in cancer cells of human colon cancer (Caco-3) $(\mathrm{IC50}=33.92,15.01,3.98 \mu \mathrm{g} / \mathrm{ml})$, human breast cancer (MCF7) $($ IC50 = 12.79, 0.378, 10.73 $\mu \mathrm{g} / \mathrm{ml})$, human lung cancer cell line (A549) (IC50 = $27.37,0.45,2.46 \mu \mathrm{g} / \mathrm{ml}$ ), respectively. Moreover, food additives exhibited cytotoxic activity on normal lung cell lines (Wi38) (IC50 = 4.25, 0.733, $18.14 \mu \mathrm{g} / \mathrm{ml}$ ). These data indicated that food additives decreased cell viability in malignant and nonmalignant cells as well as confirmed the occurrence of their cytotoxic effects.

Keywords: Monosodium glutamate; saffron, sodium benzoate, breast cancer, colon cancer, lung cancer, neutral red assay.

\section{INTRODUCTION}

Any substance added to food is apt to change any of its attributes from the beginning of the production phase and ending to the consumer, it is added in order to improve preservation or sensory qualities or reduction of exposing consumers to poisoning and other health hazards (Cann et al 2007).

Monosodium glutamate (MSG) is widely used as flavoring agent in the whole world. It is added to the food either as a purified monosodium salt or as a component of a mixture of amino acids and small peptides resulting from the acid or enzymatic hydrolysis of proteins (Schwartz, 2004). When it is added to food in relatively small quantities, the palatability of this food increases (Vindini et al 2010). Substantial evidence indicated that the sensory basis for this effect is due to MSG stimulation of the taste buds (Garattini, 2000). Some investigations aimed at determining the effect of MSG on body organs, showed that it inflicted DNA damage at all concentrations in isolated human lymphocytes after $1 \mathrm{~h}$ in vitro exposure. It was demonstrated that MSG is genotoxic to the human peripheral blood lymphocytes (Ataseven et al 2016). Osfor et al (1997) indicated that kidney, liver, brain, and heart weight significantly increased in rats treated with MSG. MSG in high doses produced neuroendocrine abnormalities and neuronal degeneration (Moreno, 2005), and oxidative damage in different organs (Farmobi and Onyema, 2006; Pavlovic et al 2007). Furthermore, glutamate in high concen- 
trations, particularly in postnatal period, could act as a neurotoxin (excitotoxin) (Eweka et al 2011).

Although sodium benzoate (SB) is accepted as a safe substance, but short-term exposure can cause irritation of eyes, skin and respiratory tract, yet prolonged or repeated contact may cause high skin sensitization (Schossler et al 2004). Using high doses could cause the release of histamine and prostaglandin, ulcers and gastric mucus secretion changes (Shahmohammadi et al 2016). The genotoxic potential of sodium benzoate associated with chromosomal aberration, sister chromatid exchanges and cell cycle proliferation index analysis in the cultured human peripheral lymphocytes. In vitro genotoxicity tests detected that it can induce genetic damage, directly or indirectly, by different mechanism. All substances could be considered as markers of early biological effects of carcinogenic exposure (Patel and Ramani, 2017).

Saffron from (Crocus sativus $\boldsymbol{L}$.) is considered as the most expensive traditional spice, was demonstrated to affect pancreatic cancer cell line which was highly sensitive to crocin-mediated growth inhibition and apoptotic cell death. Although the molecular mechanisms of crocin action were not yet clearly understood, it appears to have potential as a therapeutic agent (Jemal et al 2009). Although, many studies have investigated the effect of saffron and its active constituents in the prevention and treatment of cancer, so far, the exact mechanism of action has not been cleared yet on anticancer and toxic effects of saffron and its constituents as a chemo-preventive herb and its mechanisms of action was reported (Milajerdi et al 2016). Saffron could induce apoptosis in MCF-7 cells in which it was dependent on caspase activation. It has been suggested that saffron could cause MCF-7 cell death, in which apoptosis or programmed cell death plays an important role. Saffron could be also considered as a promising chemotherapeutic agent in breast cancer treatment (Mousavi et al 2009).

The NR assay is based on the integration of the supravital dye inside the lysosomes of viable cells. If toxic agents injure the lysosomal membrane, damaged or dead cell cannot keep the dye. After NR dye has been extracted from lysosome, it is quantified spectrophotometrically (Fotakis and Timbrell, 2006).

The objective of this study was to assess the potential cytotoxic and apoptotic effects of common food additives on human cell growth.

\section{MATERIALS AND METHODS}

\section{Materials}

\subsection{Human cell lines and cultures}

Four different types of human cell lines were used; namely, cancerous colon carcinoma (Caco3), breast carcinoma (MCF7), lung carcinoma (A549) and normal lung cell line (Wi38) which was used as the control [obtained from the American Type Culture Collection (ATCC), Manassas, Virginia, USA]. The plates with human cell lines were incubated at $37^{\circ} \mathrm{C}$ in $5 \% \mathrm{CO} 2$ for 24 hours to obtain monolayer confluence.

\subsection{Food additives}

Three different types of food additives (MSG, SB and saffron) were used in this study [obtained from Sigma Chemical Company, St. Louis, USA].

\section{Methods}

In vitro cytotoxicity by neutral red assay (NR assay)

In vitro neutral red cytotoxicity assay based on the initial protocol described by Fotakis and Timbrell (2006) was carried out. Culture media containing three different concentrations of MSG at $0.25,0.5$ and $1 \mathrm{mg} / \mathrm{ml}$ were used. SB; with three different concentrations at $0.02,0.05$ and 0.1 $\mathrm{mg} / \mathrm{ml}$, and saffron with three different concentrations at $0.5,1$ and $1.5 \mathrm{mg} / \mathrm{ml}$ were added in triplicates. Medium without chemical compounds as untreated control was used also. The dye-medium with doxorubicin was removed and the plates were washed with formol-calcium $(10 \mathrm{ml}$ of $40 \%$ formaldehyde, $10 \mathrm{ml}$ of $10 \%$ anhydrous calcium chloride, and $80 \mathrm{ml}$ water). Five hundred $500 \mu \mathrm{l}$ of acetic acid-ethanol (one $\mathrm{ml}$ glacial acetic acid in $100 \mathrm{ml}$ $50 \%$ ethanol) was added and the plates were kept for $15 \mathrm{~min}$ at room temperature to extract the dye. Plates were then shaked for a few seconds, so a complete dissolution was achieved. The absorbance of the extracted dye was measured by spectrophotometric reading (spectra max 190-Molecular devices) with $540 \mathrm{~nm}$ filter. The mean of three measurements for each concentration was determined $(n=6)$. The viability \% was estimated for having the concentration of the test chemical reflecting half the maximum concentration of cell proliferation (IC50). 
Cytotoxicity of food additives was screened on multiple cell lines and examined by NR assay (Neutral red assay). In this study, IC50 (inhibited $50 \%$ cell growth) levels were measured for doxorubicin against food additives as shown. Doxorubicin was used as a positive control, which is known to exhibit cytotoxic activity against human cancer cell. This study detects the possible effects of the three common food additives MSG, SB and saffron on some human cancer cells.

\section{RESULTS AND DISCUSSION}

1. In vitro assay for cytotoxic activity on human cancer and normal cell lines (neutral red assay)

\subsection{The effect of monosodium glutamate on} the viability percentages of four cell lines.

In the present study, IC50 levels were measured for doxorubicin which was used as a positive control against each food additives. The results showed that MSG induced profound cytotoxicity in some cancer cells (Table 1), i.e., human colon cancer $($ Caco-3) $($ IC50 $=33.92 \mu \mathrm{g} / \mathrm{ml})$, human breast cancer (MCF7) $($ IC50 $=12.79 \mu \mathrm{g} / \mathrm{ml})$, human lung cancer cell line (A549) $($ IC50 $=27.37 \mu \mathrm{g} / \mathrm{ml})$,. Moreover, food additives exhibited cytotoxic activity on normal lung cell lines (Wi38) (IC50 = $4.25 \mu \mathrm{g} / \mathrm{ml}$ ) (Fig. 1). These data indicated that MSG decreased cell viability in malignant and nonmalignant cells as well as confirmed the occurrence of cytotoxic effect.

Table 1. The effect of MSG on the viability percentages of the four cell lines.

\begin{tabular}{|ccccc|}
\hline $\begin{array}{c}\text { Concentra- } \\
\text { tion }(\mu \mathrm{g} / \mathrm{ml})\end{array}$ & \multicolumn{4}{c|}{ Viability of Cell line by MSG } \\
\cline { 2 - 5 } & Caco-3 & MCF7 & A549 & Wi38 \\
\hline 0.25 & 100 & 85.7 & 60.7 & 96.7 \\
0.5 & 97.8 & 81.8 & 59.8 & 81.7 \\
1 & 98.5 & 74.8 & 50.5 & 80 \\
IC50 & $\mathbf{3 3 . 9 2}$ & $\mathbf{1 2 . 7 9}$ & $\mathbf{2 7 . 3 7}$ & $\mathbf{4 . 2 5}$ \\
\hline
\end{tabular}

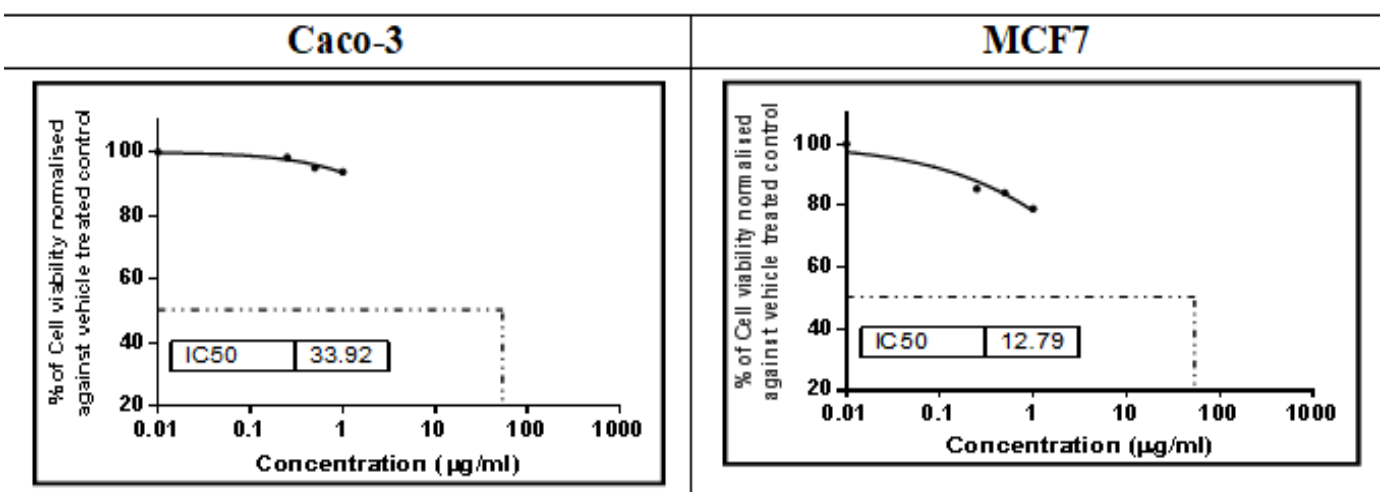

1.a. Caco-3 and MCF7

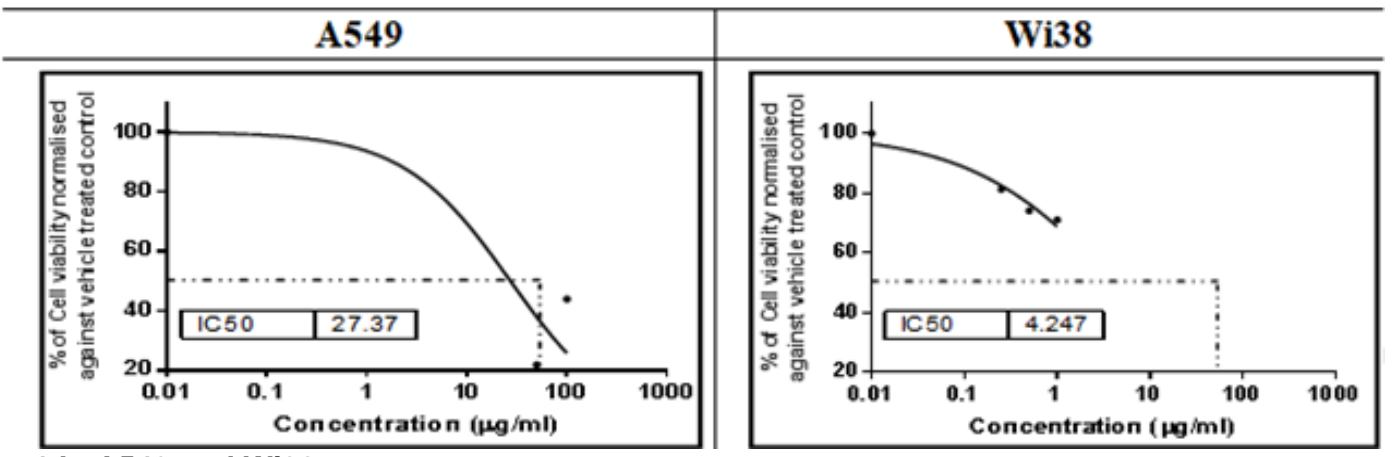

1.b. A549 and Wi38

Fig. (1 a, b). Dose-dependent growth inhibition by the doxorubicin as a positive control against MSG. Nonmalignant human lung cells (Wi38) and malignant human cells (Caco-3, MCF7, A549 cells). Viability were quantified by NR assay. Results are mean $\pm(n=3)$. ${ }^{*} p<0.05$ to $\alpha$ compared with the control. 
This toxicity was consistent with morphologic changes including reduction in cells of four cell lines (Caco-3, MCF7, A549 and Wi38), no morphological changes were shown in Wi38 cells (Fig. 2). Investigations aimed at determining the effect of MSG on body organs, revealed the occurrence of DNA damage at all concentrations in isolated human lymphocytes after $1 \mathrm{~h}$ in vitro exposure. It was demonstrated that MSG was genotoxic to the human peripheral blood lymphocytes in vitro, (Ataseven et al 2016). Osfor et al (1997) indicat- ed that kidney, liver, brain, and heart weight were significantly increased in rats treated with MSG. Glutamate in high doses and produced neuro endocrine abnormalities and neuronal degeneration (Moreno et al 2005), and oxidative damage in different organs (Farmobi \& Onyema, 2006 and Pavlovic et al 2007). Furthermore, glutamate in high concentrations, especially at postnatal period, could act as a neurotoxin (excitotoxin) (Eweka et al 2011).

\begin{tabular}{|c|c|c|c|c|c|}
\hline \multicolumn{2}{|c|}{ Concentration $(\mu \mathrm{g} / \mathrm{ml})$ of MSG } & \multicolumn{4}{|c|}{ Four cell lines } \\
\hline & & Caco-3 & MCF7 & $\overline{A 549}$ & Wi38 \\
\hline \multirow[t]{2}{*}{0.25} & Negative & & & & \\
\hline & Positive & & & & \\
\hline \multirow[t]{2}{*}{0.5} & Negative & & & & \\
\hline & Positive & & & & \\
\hline \multirow[t]{2}{*}{1} & Negative & & & & \\
\hline & Positive & & & & \\
\hline
\end{tabular}

Fig. 2. MSG induces morphologic changes and affects the viability of cultures (CaCo-3, MCF7, A549 and Wi38) cells. Negative control and positive control of all concentrations, $0.25 \mu \mathrm{g} / \mathrm{ml}, 0.5 \mu \mathrm{g} / \mathrm{ml}, \mathrm{I} \mu \mathrm{g} / \mathrm{ml}$. Cells were incubated with MSG for $48 \mathrm{~h}$.

\subsection{The effect of SB on the viability percent- ages of four human cell lines}

The results showed that SB induced marked cytotoxicity in some cancer cells (Table 2), i.e., human colon cancer (Caco-3) $($ IC50 $=15.01 \mu \mathrm{g} / \mathrm{ml})$, human breast cancer (MCF7) $(\mathrm{IC50}=0.378 \mu \mathrm{g} / \mathrm{ml})$, human lung cancer cell line (A549) (IC50 $=0.45$ $\mu \mathrm{g} / \mathrm{ml}$ ). Moreover, food additives exhibited cytotoxic activity on both cancer and normal lung cell lines
(Wi38) which IC50 $=0.733 \mu \mathrm{g} / \mathrm{ml}$ showed (Fig. 3) . These data indicated that SB decreased cell viability in malignant and non-malignant cells as well and confirmed the occurrence of cytotoxic effect. This toxicity was consistent with morphologic changes including reduction in the four cell lines (Caco-3, MCF7, A549 and Wi38) volume while rounding and no morphological changes were observed in Wi38 cells (Fig. 4). 


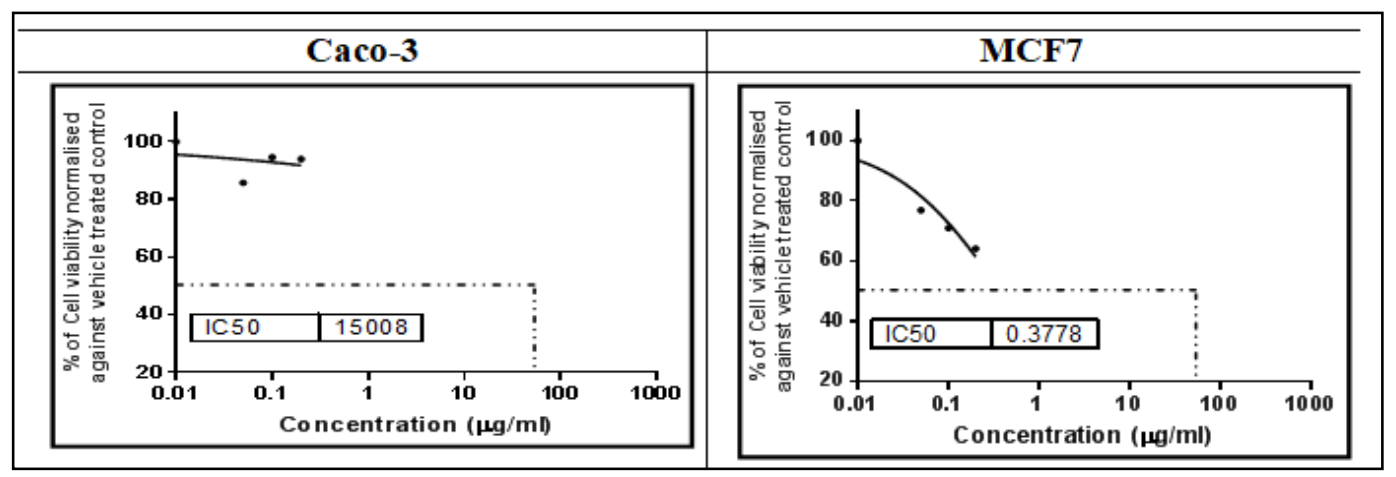

\section{3.a. Caco-3 and MCF7}

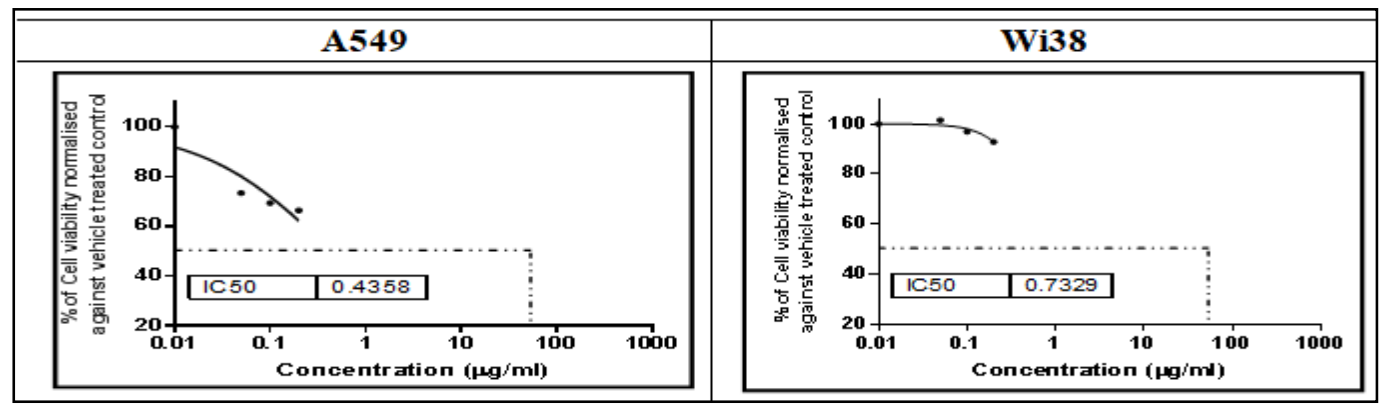

\section{3.b. $A 549$ and Wi38}

Fig. 3 a,b: Dose-dependent growth inhibition by the doxorubicin as a positive control against SB. Non-malignant human lung cells (Wi38) and malignant human cells (Caco-3, MCF7 and A549). Viability were quantified by NR assay. Results are mean $\pm(n=3)$. ${ }^{*} p<0.05$ to be compared to the control.

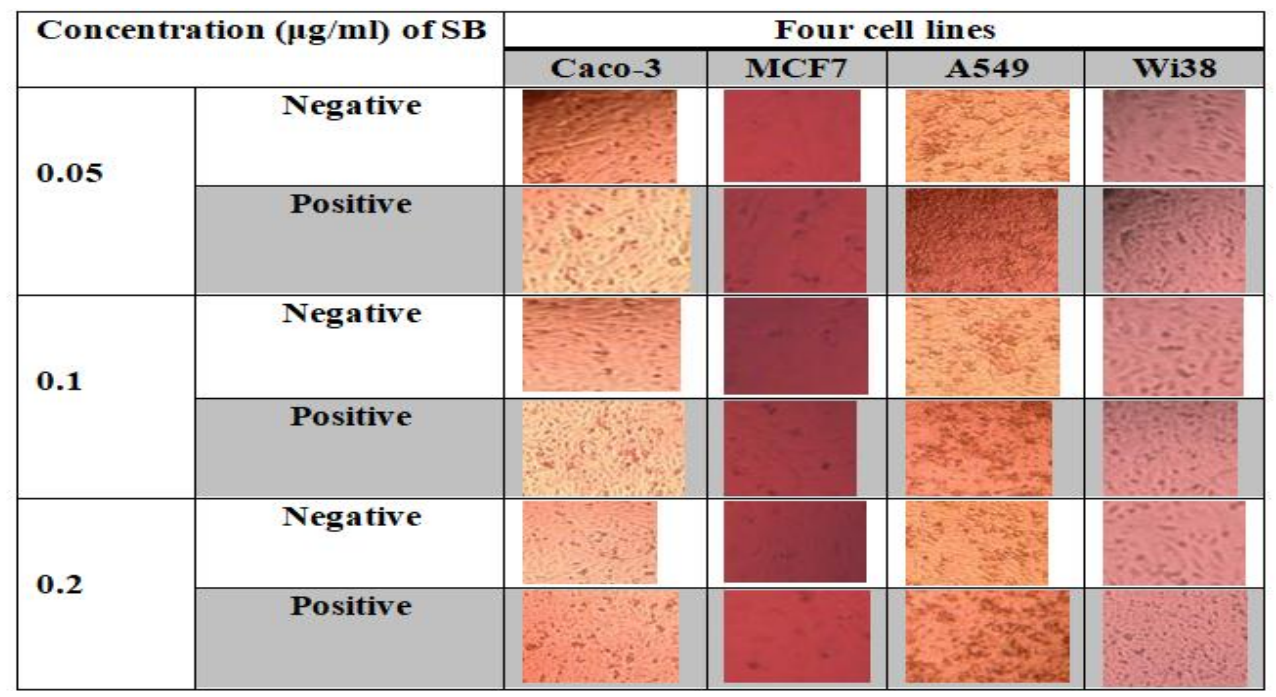

Fig. 4. SB induces morphologic changes and affects the viability of cultures (CaCo-3, MCF7, A549 and Wi38) cells. Negative control and positive control of all concentrations, $0.5 \mu \mathrm{g} / \mathrm{ml}, 1$ $\mu \mathrm{g} / \mathrm{ml}, 1.5 \mu \mathrm{g} / \mathrm{ml}$. Cells were incubated with SB for $48 \mathrm{~h}$. 
Table 2. The effect of sodium benzoate on the viability percentages of the four cell lines.

\begin{tabular}{|ccccc|}
\hline $\begin{array}{c}\text { Concentration } \\
(\mu \mathrm{g} / \mathrm{ml})\end{array}$ & \multicolumn{4}{c|}{ Viability of Cell line by SB } \\
\cline { 2 - 5 } & $\begin{array}{c}\text { Caco- } \\
\mathbf{3}\end{array}$ & MCF7 & A549 & Wi38 \\
\hline 0.05 & 100 & 71 & 67.4 & 100 \\
0.1 & 100 & 64 & 63.4 & 95.9 \\
0.2 & 93 & 55.4 & 60.8 & 90 \\
IC50 & $\mathbf{1 5 . 0 1}$ & $\mathbf{0 . 3 8}$ & $\mathbf{0 . 4 5}$ & $\mathbf{0 . 7 3}$ \\
\hline
\end{tabular}

Although sodium benzoate is accepted as a safe substance, but short-term exposure can cause irritation of eyes, skin and respiratory tract, yet prolonged or repeated contact may cause high skin sensitization (Schossler et al 2004). Using high doses cause release of histamine and prostaglandin, ulcers and gastric mucus secretion changes (Shahmohammadi et al 2016). The genotoxic potential of sodium benzoate was associated with chromosomal aberration, sister chromatid exchanges, and cell cycle proliferation index analysis in the cultured human peripheral lymphocytes. In vitro genotoxicity tests detected that it can induce genetic damage, directly or indirectly, by different mechanisms. In general, SB could be considered as marker of early biological effects of carcinogenic exposure (Patel and Ramani, 2017).

\subsection{The effect of saffron on the viability of can- cer cell lines}

The results showed that saffron induced substantial cytotoxicity in some cancer cells (Table 3 ), i.e., human colon cancer (Caco-3) (IC50 = $3.984 \mu \mathrm{g} / \mathrm{ml})$, human breast cancer (MCF7) $($ IC50 = $10.73 \mu \mathrm{g} / \mathrm{ml}$ ), human lung cancer cell line (A549) $(\mathrm{IC} 50=2.457 \mu \mathrm{g} / \mathrm{ml})$. Moreover, food additives exhibited cytotoxic activity on normal lung cell lines (Wi38) $(\mathrm{IC50}=18.14 \mu \mathrm{g} / \mathrm{ml})$ (Fig. 5). These data indicated that saffron decreased cell viability in malignant and non-malignant cells as well and confirmed the occurrence of cytotoxic effect. This toxicity was consistent with morphologic changes including reduction in the four cell lines (Caco-3, MCF7, A549 and Wi38) volume and rounding and no morphological changes were shown in Wi38 cells (Fig. 6).

Table 3. The effect of saffron on the viability percentages of the four cell lines (Caco-3, MCF7, A549 and Wi38)

\begin{tabular}{|ccccc|}
\hline Concentra- & \multicolumn{4}{c|}{ Viability of Cell line by saffron } \\
\cline { 2 - 5 } tion $(\mu \mathrm{g} / \mathrm{ml})$ & Caco-3 & MCF7 & A549 & Wi38 \\
\hline 0.5 & 100 & 73 & 50 & 97.6 \\
1 & 91.4 & 72 & 35 & 92 \\
1.5 & 88.5 & 67 & 9.9 & 87 \\
IC50 & $\mathbf{3 . 9 8 4}$ & $\mathbf{1 0 . 7 3}$ & $\mathbf{2 . 4 5 7}$ & $\mathbf{1 8 . 1 4}$ \\
\hline
\end{tabular}

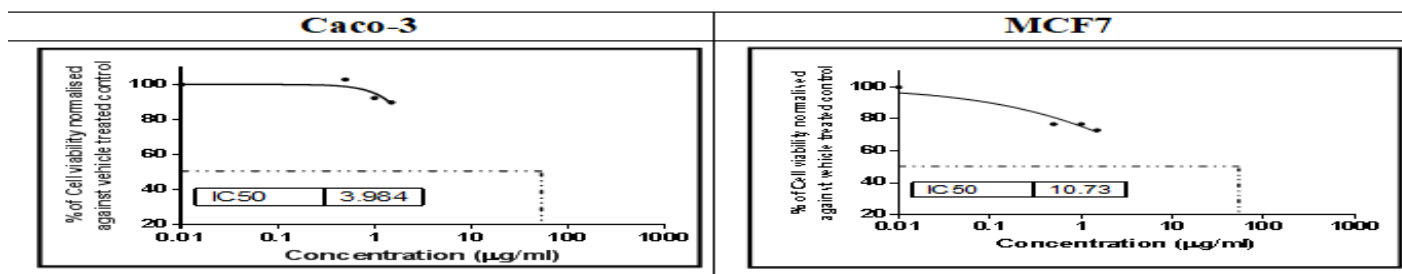

5.a. Caco-3 and MCF7

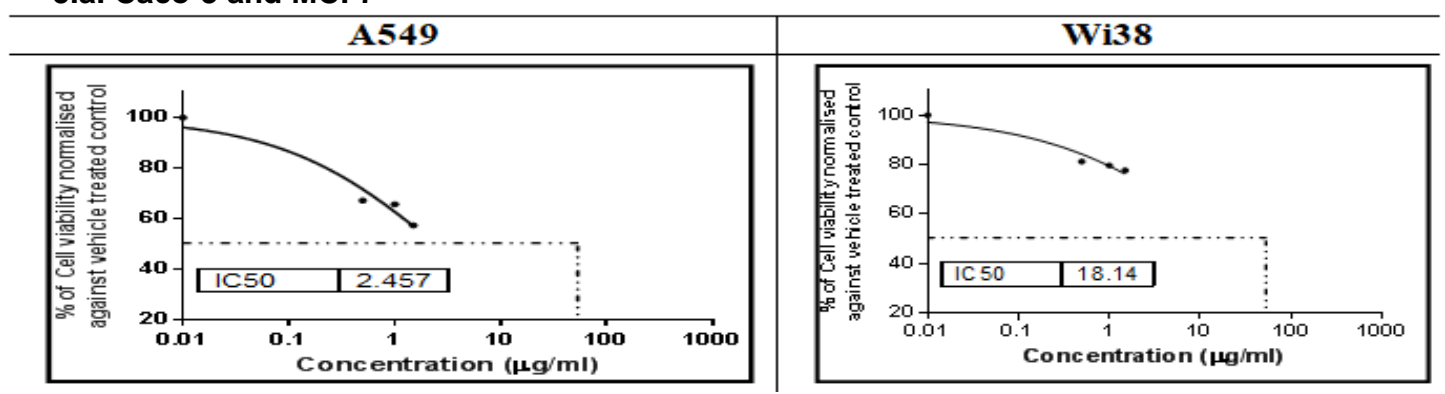

5.b. A549 and Wi38

Fig. (5a,b): Dose-dependent growth inhibition by the doxorubicin as a positive control against saffron. Non-malignant human lung cells (Wi38) and malignant human cells (A549, MCF7 and Caco-3). Viability were quantified by NR assay. Results are mean $\pm(n=3)$. ${ }^{*} p<0.05$ to be compared to the control. 


\begin{tabular}{|c|c|c|c|c|c|}
\hline \multirow{2}{*}{\multicolumn{2}{|c|}{ Concentration $(\mu \mathrm{g} / \mathrm{ml})$ of Saffron }} & \multicolumn{4}{|c|}{ Four cell lines } \\
\hline & & Caco-3 & MCF7 & $\mathbf{A 5 4 9}$ & Wi38 \\
\hline \multirow{3}{*}{0.5} & Negative & & & & \\
\hline & & & & & \\
\hline & Positive & & & & \\
\hline \multirow{2}{*}{1} & Negative & & & & \\
\hline & Positive & & & $B$ & \\
\hline \multirow[b]{2}{*}{1.5} & Negative & & & & \\
\hline & Positive & & & & \\
\hline
\end{tabular}

Fig. 6. Saffron induces morphologic changes and affects the viability of cultures (Caco-3, MCF7. A549 and Wi38) cells. Negative control and positive control of all concentrations, $0.5 \mu \mathrm{g} / \mathrm{ml}, 1 \mu \mathrm{g} / \mathrm{ml}, 1.5 \mu / \mathrm{ml}$. Cells were incubated with saffron for $48 \mathrm{~h}$.

It was demonstrated that pancreatic cancer cell line to be highly sensitive to crocin-mediated growth inhibition and apoptotic cell death. Although the molecular mechanisms of crocin action are not yet clearly understood, it appears to have potential as a therapeutic agent (Jemal et al 2009). On the contrary, many studies have investigated the effect of saffron and its active constituents in the prevention and treatment of cancer, so far, the exact mechanism of action has not been cleared yet on anticancer and toxic effects of saffron and its constituents as a chemo-preventive herb and its mechanisms of action (Milajerdi et al 2016). Saffron was reported to induce apoptosis in MCF-7 cells in which apoptosis was dependent on caspase activation. It has been suggested that saffron could cause MCF-7 cell death, in which apoptosis or programmed cell death plays an important role. Saffron could be also considered as a promising chemotherapeutic agent in breast cancer treatment (Mousavi et al 2009).

It is evident from the aforementioned discussion that the studied food additives could inflect some serious health hazards if they are added haphazardly in foods and preveradges. Therefore, strict control of their use in accordance with the special regulations set by the Food and Drug Ad- ministration (FDA) and World Health Organization (WHO) to insure their biosafety for human consumption.

\section{REFERENCES}

Ataseven, N., Yuzbasioglu, D., Keskin, A.C. and Unal, F., 2016. Genotoxicity of monosodium glutamate. Food Chem. Toxicol., 91, 8-18.

Cann, M., Barrett D., Cooper A., Crumpler A., Dalen D., Grimshaw L., Kitchin K. and Lok E.K., 2007. "Food additives and hyperactive behaviour in 3-year-old and 8/9-year-old children in the communit a randomised, doubleblinded, placebo-controlled trial. Journal of Experimental Psychology: General", 370, 1000-1016.

Eweka, A.O., Igbigbi, P.S. and Uchey, R.E., 2011. Histochemical studies of the effects of monosodium glutamate on the liver of adult Wistar rats. Ann. Med. Health Sci. Res., 1, 2129.

Farmobi, E.O. and Onyemia, O.O., 2006. Monosodium glutamate- induced oxidative damage and genotoxicity in the rat: Modulatory role of vitamin C, vitamin E and quercetin. Hum Exp. Toxicol., 25, 251 - 259.

Fotakis, G. and Timbrell, J.A., 2006. In vitro cytotoxicity assays: comparison of LDH, neutral 
red, MTT and protein assay in hepatoma cell lines following exposure to cadmium chloride. Toxicol Lett., 160, 171-177.

Garattini S., 2000. Glutamic acid, twenty years later. J. Nutr., 130, 901S-909S.

Jemal, A., Siegel, R., Ward, E., Hao, Y., Xu, J. and Thun, M.J., 2009. Cancer Statistics, both sexes female both sexes estimated deaths. CA Cancer J. Clin., 59(4), 1-25.

Milajerdi, A., Djafarian, K., and Hosseini, B. 2016. The toxicity of saffron (Crocus sativus $L$.) and its constituents against normal and cancer cells. Journal of Nutrition and Intermediary Metabolism, 3, 23-32.

Moreno, M.C., 2005. Effect of glaucoma on the retinal glutamate/glutamine cycle activity. The FASEB Journal. Experimental Eye Research 81, 71-80.

Mousavi S.H., J. Tavakkol-Afshari, A. Brook and I. Jafari-Anarkooli , 2009. Role of caspases and Bax protein in saffron-induced apoptosis in MCF-7 cells, Food Chem., Toxicol. 47(8), 1909-1913.

Osfor, M., El-Desouky, S.A. and El- Leithy, N.A., 1997. Effect of dietary intake of monosodium glutamate on some nutritional and biochemical traits in albino rats. Eg. J. Comp Path Clin Path., 10, 131- 139.
Patel, D. and Ramani, R., 2017. In vitro determination of genotoxic effects of sodium benzoate preservative on human peripheral blood lymPhocytes, 6(3), 20-26.

Pavlović, V., Cekić, S., Kocić, G., Sokolović, D. and Živković, V., 2007. Effect of monosodium glutamate on apoptosis and $\mathrm{Bcl}-2 / \mathrm{Bax}$ protein level in rat thymocyte culture. Physiological Research, 56(5), 619-626.

Schossler, P., Nascimento F.I., Santos, F.L., Melecchi, M.I., Rodrigues V.M. and Bastos C.E., 2004. Selective extraction of benzoic acid from landfill leachate by solid-phase extraction and ion- exchange chromatography. J. Chromatogr. A., 1027(1-2), 167-170.

Schwartz J. R. 2004. In bad taste, the MSG " syndrome" MSG. The $5^{\text {th }}$ Annual Conference of the Weston A. Price Foundation. 3, 370-373.

Shahmohammadi, M., Javadi, M. and Nassiriasl, M., 2016. An overview on the effects of sodium benzoate as a preservative in food products. Biotechnology Heatlh. Sci., 3(3), 1-5. https://doi.org/10.17795/bhs-35084. Review

Vindini, N.A., Nayantara, A.K., Ramaswamy, C., Gowda, D., Ahmed, B. and Bhat, R., 2010. Study on evaluation of monosodium glutamate induced oxidative damage on renal tissue on adult Wistar rats. J. Chin. Clin. Med., 3, 112115. 
المؤتمر الرابع عشر لبحوث التنمية الزراعية،

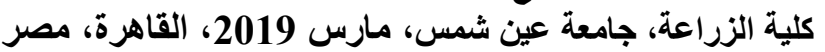

مجلا(27)، عدد (1)، عدد خاص مارس، مارس، 585-585، 2019

Website: http://strategy-plan.asu.edu.eg/AUJASCl/

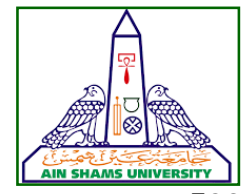

تقييم التأثيرات الوراثية لبعض المضافات الغذائية على بعض الخلايا السرطانية البشرية

[55]

شيماء السيد رشاد - فتحى محمد عبد التواب- إيمان محمود فهمى- أشرف جميل عطالله-

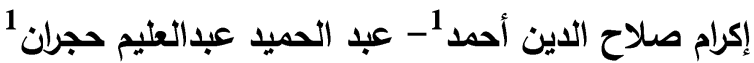

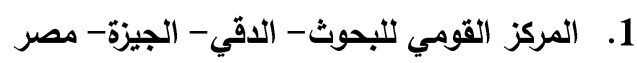

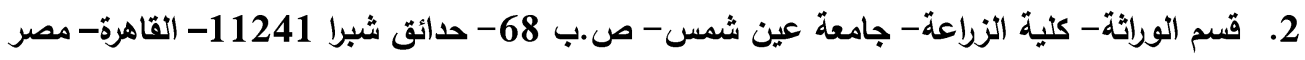

*Corresponding author: shimaar30@yahoo.com

Received 18 December, 2018, $\quad$ Accepted 30 December, 2018

الوراثية في الخلايا السرطانية والطبيعية. كان التأثير

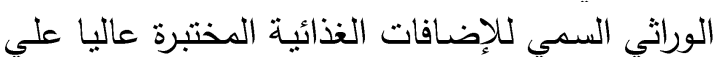

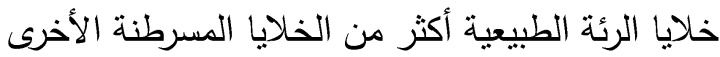

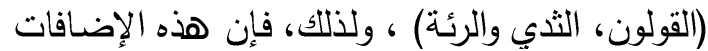

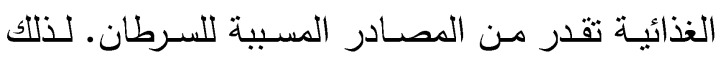

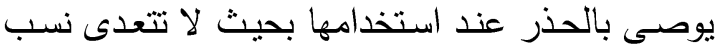
الإضافة للأغذية عن الحدود الآمنة حسب البرونة لألتوكول

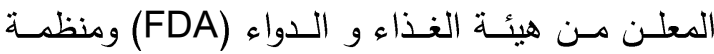

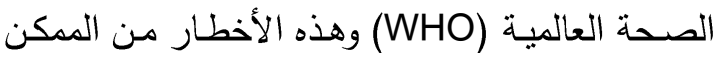
حدوثها على صحة المستهلك إذا تجاوزت هذه الإنسار هن النسب.

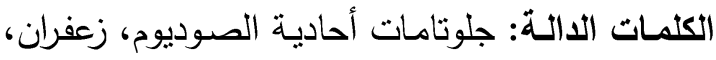

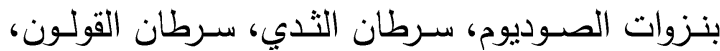

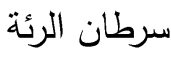

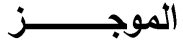

ثبت مؤخرا أن بعض الإضافات الغذائية المستخدمة

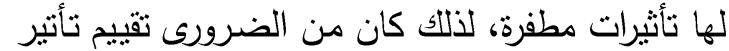

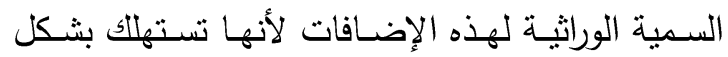
متكرر مـن قبـل البشـر فـى وجباتهم اليوميـة. تم تقييم تأثثر السمية الوراثية لكل من بنزوات الصوديوم الئر (SB)،

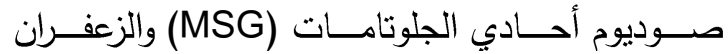
(Aaffron)

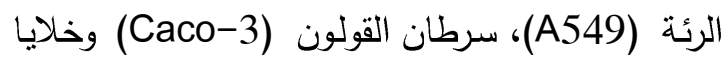

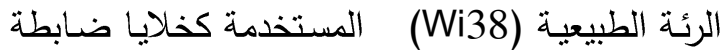

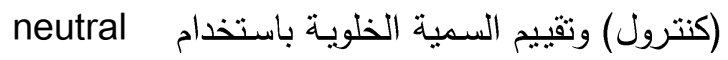
red cytotoxicity

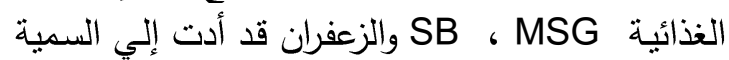

